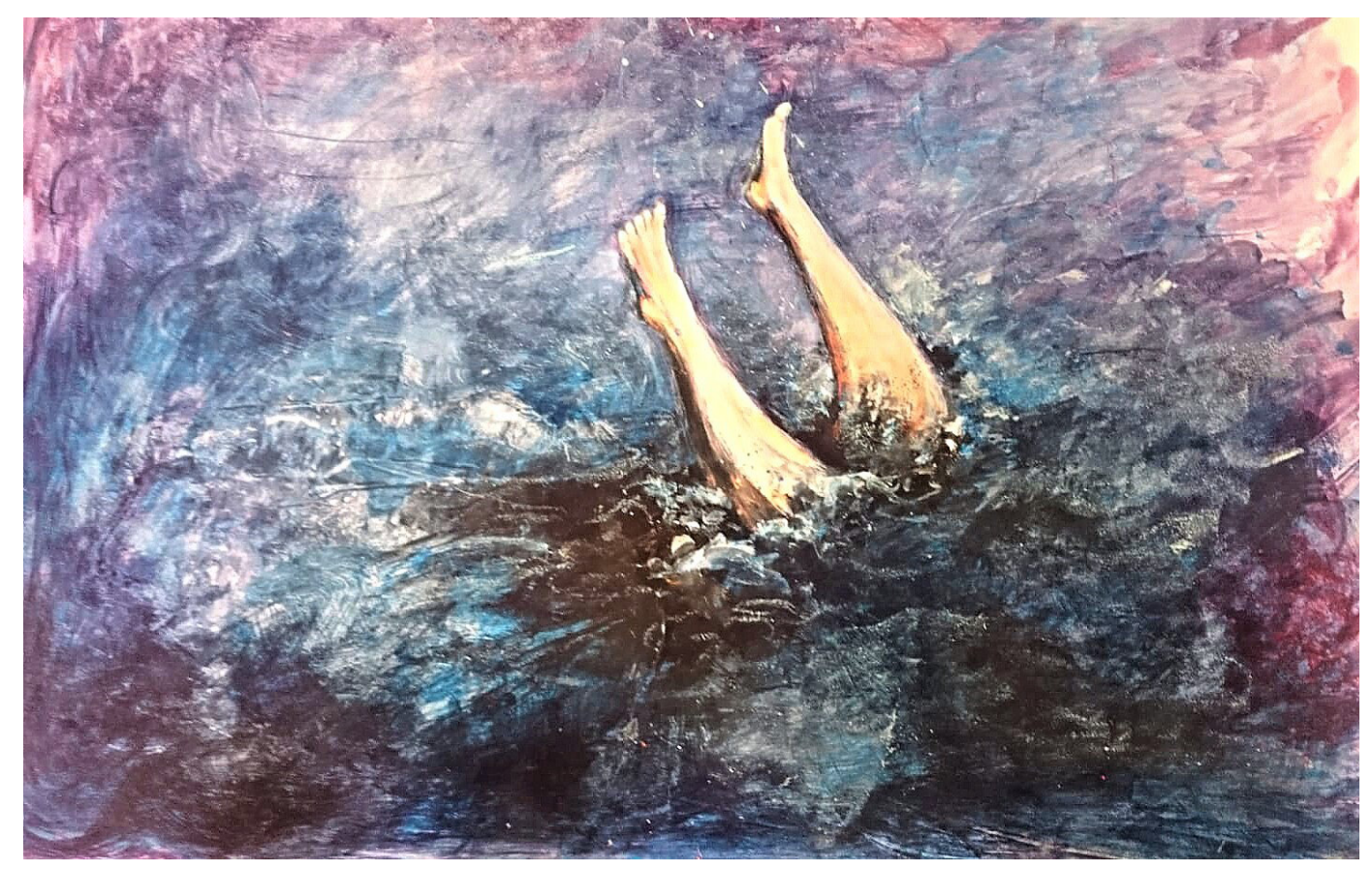

\title{
Inmersión creadora
}

\section{Técnica}

Técnica mixta. $60 \times 50 \mathrm{~cm}$.

\section{Reflexión}

El proceso de creación me ha acompañado durante estos meses de confinamiento. Diferentes técnicas, soportes y lenguajes artísticos han dado forma a mis pensamientos, emociones y sentimientos durante este tiempo tan particular que estamos viviendo. La obra Inmersión creado$r a$ representa todo este proceso de sumergirme en la creación para dar salida y expresión a la amalgama de pensamientos y emociones que sentía.

\section{Autora}

Patricia Marco. Máster de Arteterapia en la Universidad Politécnica de Valencia (2015-2018).

Arteterapia: papeles de arteterapia y educación artística para la integración social.

Monográfico: Las miradas del arte y el arteterapia en tiempos de la Covid19. ISSN-e: 1988-8309 https://dx.doi.org/10.5209/arte.75921 